\title{
A Contrastive Analysis of Antonymous Prepositional Pairs in Croatian and Russian
}

\author{
Ivana Matas Ivanković ${ }^{[0000-0002-9796-8346]}$ \\ Institute of Croatian Language and Linguistics, Republike Austrije 16, 10000 Zagreb, Croatia \\ imataseihjj.hr
}

\begin{abstract}
Structures consisting of two prepositional phrases with antonymous prepositions followed by a noun phrase (NP) usually have unique meaning, which provides a reason to treat them as phraseological units. In Croatian and Russian, these structures are $o d / o m$ 'from' $+N P 1_{G E N}+d o / \partial o$ 'to' $+N P 2_{G E N}$, $s / c$ 'from' $+N P 1_{G E N}+n a / H a$ 'onto' $+N P 2_{A C C}, i z / u 3$ 'out of' $+N P 1_{G E N}+u /$ ${ }_{B}$ 'into' $+N P 2_{A C C}$. These are grammatically fixed units, but lexically, they can be placed on a scale from fixed to flexible. On one side of the scale, the form is productive and its members are not lexically restricted. On the other side, they come as lexically filled idioms that cannot be translated word for word. The goal of this paper is to examine the similarities and differences between units with specific syntactic structure in Croatian and Russian, two languages that are genetically related.
\end{abstract}

Keywords: Antonymous Prepositional Pairs, Croatian, Russian.

\section{$1 \quad$ Introduction}

This paper compares syntactic structures in Croatian and Russian that contain two prepositional phrases with antonymous prepositions that refer to one whole. The first prepositional phrase in this kind of pair indicates a starting point, while the other refers to an ending point. These structures are $o d / o m$ 'from' $+N P 1_{G E N}+d o / \partial o$ 'to' + $N P 2_{G E N}, s / c$ 'from' $+N P 1_{G E N}+n a / H a$ 'onto' $+N P 2_{A C C}, i z / u 3$ 'out of' $+N P 1_{G E N}+$ $u /$ r 'into' $+N P 2_{A C C}$. This type of unit has been analysed in Croatian [1] and Russian $[2,3]$, but a detailed comparison of these constructions in the two languages has not yet been performed, especially for idioms. The aim of this research is to establish the similarities and differences between these structures in Croatian and Russian, as such complex structures, if taken for granted, can cause difficulties in second language learning and in translation.

The paper is structured as follows: first, the grammatical properties of the structure are described, then formal idioms are presented, and then substantive idioms are compared. Since there is no parallel Croatian-Russian corpus, the examples in the first 
part are taken from the Croatian hrWaC corpus ${ }^{1}$ (http://nlp.ffzg.hr/resources/corpora/hrwac/) and the Russian National Corpus ${ }^{2}$ (http://www.ruscorpora.ru/). The texts were chosen independently but are as similar as possible, meaning that if they were translated from one language to another, the same structure would be used. ${ }^{3}$

\section{Structure}

Antonymous prepositional pairs have fixed structure, consisting of two prepositional phrases with antonymous prepositions (od / om 'from' - do / do 'to'; iz / us 'out of' u / в 'into'; $s$ / c 'from' - na / нa 'onto'). Formally, prepositional phrases can come separately, but the meaning is incomplete without one of the parts. In the pair od/om 'from' - do / $\partial o$ 'to', both nominal phrases following the preposition come in the genitive case. In the pair $i z$ / uз 'out of' $-u$ / 8 'into' and $s / c$ 'from' $-n a /$ н 'onto', the first nominal phrase is in genitive (in Croatian and in Russian, $s$ / $c$ can also come with the instrumental), while the second is in the accusative (in Croatian and Russian, the prepositions $u$ / 8 and na / нa can also come with the locative case - the accusative indicates a goal). The grammatical structure of these units is determined and fixed, but the nominal phrases that appear in them can be free or fixed.

\section{Formal idioms}

Fillmore et al. [4: 505] distinguishes between substantive or lexically filled idioms and formal or lexically open idioms. Formal idioms are syntactic patterns dedicated to semantic and pragmatic purposes not knowable from their form alone. Antonymous prepositional pairs with $o d / o m$ 'from' - do / do 'to', $i z / u 3$ 'out of' $-u$ / 8 'into', $s / c$ 'from' - $n a$ / $a$ 'onto' are syntactic patterns that can be filled by different noun phrases. As a pair, od / om 'from' + NP1 $1_{G E N}+d o / \partial o$ 'to' $+N P 2_{G E N}$ can have (a) spatial meaning of stretching or prolonging: jedna od najtežih ruta, od Aljaske pa do Ognjene zemlje 'one of the most difficult routes, from Alaska to Tierra del Fuego' I мышицы ног от бедра до колена 'leg muscles from the thighs to the knees', (b) temporal meaning of lasting: trajati od kasne zime do kasnog ljeta 'last from late winter to late summer' / в возрасте от 12 до 17 лет 'from the age of 12 to 17', (c) quantitative meaning: naklada od 300 do 1000 primjeraka 'an edition of 300 to 1000 copies' / по иене от 20 до 80 рублей 'at the price of 20 to 80 rubles', (d) the meaning of a range in a broad sense, referring to many constituents belonging to one whole (these noun phrases frame everything in between, whether referring to objects, processes, or something else): pripremiti sve, od omleta do svježeg soka od naranče 'prepare every-

\footnotetext{
${ }^{1}$ The search, used the following regular expressions: [lemma="od"][]\{1,3\}[lemma="do"], [word="s"\&tag="S.*"][tag="....g"] $\{1,3\}[$ lemma="na"], [lemma="iz"][]\{1,3\}[lemma="u"].

${ }^{2}$ In the lexical and grammatical search, the first preposition of the pair was set in the "word" field, while the other one was set in the second "word" field at a distance of 1-3.

${ }^{3}$ The first example is in Croatian, while the Russian example follows the slash. The English translation is located in single quotation marks.
} 
thing, from omelettes to fresh orange juice' / иветки от розовых до ярко-красных 'flowers from pink to bright red'. The preposition $i z / u_{3}$ 'out of' primarily refers to a starting point, but unlike od/om, the activity begins in a space that is perceived as closed or bounded. $U / 8$ 'into' has the opposite meaning, referring to a space inside which an action ends. $S$ / $c$ 'from' with the genitive primarily means that an action has begun on the upper or outer part of an object. $\mathrm{Na} / \mathrm{Ha}$ 'onto' with the accusative means that something or somebody has come to the upper side of something with which it is in contact. Bearing these nuances in mind, as pairs, they have (a) spatial meaning: vraćanje tekućine iz tkiva u krv 'returning fluid from tissue to the blood' / экспорт нефти и газа из России в Европу 'the export of oil and gas from Russia to Europe', (b) temporal meaning: u noći s četvrtka na petak 'on the night between Thursday and Friday' / перенесение парламентских выборов с декабря на март 'the shifting of parliamentary elections from December to March', (c) a change from one state to another: prelaziti iz osnovnog u srednje školovanje 'transition from primary to secondary schooling' / переход из юниоров в мастер-класс 'transition from the juniors to the master class'; prevoditi s hrvatskoga na ukrajinski 'translate from Croatian into Ukrainian' / переход с приема на передачу 'transfer from reception to transmission'. The Russian pairs om 'from' $+\mathrm{NP} 1_{\mathrm{GEN}}+\kappa$ 'towards' $+\mathrm{NP} 2 \mathrm{DAT}$ (om мистики к физике 'from mysticism to physics'), $c$ 'from' $+\mathrm{NP} 1_{\mathrm{GEN}}+\partial o$ 'to' + $N P 2_{G E N}$ ( с утра до ночи 'from morning till night'), and $c$ 'from' $+\mathrm{NP} 1_{\mathrm{GEN}}+$ no 'up to' + NP2 $2_{\text {ACC }}$ (с марта по декабрь 'from March to December') are also treated as grammatical structures with unique semantics [2, 3], although the prepositions in them are not completely antonymous. These pairs are not typical for Croatian, and would be translated using antonymous pairs (respectively: od mistike do fizike, od jutra do noći, od ožujka do prosinca).

Each of these pairs can obtain distributional meaning when the same noun is repeated after the prepositions: rasprostirati se od srca do srca 'spread from heart to heart', om берега до берега 'from coast to coast'; skakutati s grane na granu 'jump from branch to branch' / перепрыгивать с танка на танк 'jump from tank to tank'. This manner of pair construction can sometimes be replaced with the preposition po / no 'over' + noun (skakutati po granama 'jump about the branches' / бezamb no магазинам 'run among the shops'). The repeating noun can have temporal meaning: iz dana u dan / изо дня в день (lit. 'from day into day') 'from day to day'. Although nouns can vary, their semantics are restricted to temporal meaning, so they can be treated as substantive idioms.

\section{Substantive idioms}

Formal idioms can serve as host to substantive idioms. Their lexical makeup is (more or less) fully specified [4: 505]. Based on previous research [1] and searches of the corpus and a dictionary of idioms [5, 6], a list of 34 idioms was made, and Croatian and Russian equivalents were compared. Some idioms can be translated into several equivalents, in which case the most similar equivalent was taken into account. Based on their grammatical and lexical features, the idioms can be fully equivalent, partially equivalent, or non-equivalent. 1) Fully equivalent idioms have equivalent 
grammatical and lexical structure. Nine idioms are fully equivalent, e.g.: od glave do pete (lit. 'from head to heel') / от голови до пят, пяток (lit. 'from head to heels') 'from head to foot'; prelijevati iz šupljeg и prazno / переливать из пустого в порожнее (lit. 'transfuse from hollow into empty') 'to plough the sand'. 2) Partially equivalent idioms can be equivalent lexically or grammatically. 2a) Ten idioms are lexically equivalent: ići od Poncija do Pilata (lit. 'go from Pontius to Pilate') / ходить от Понтия к Пилату (lit. 'to walk from Pontius to Pilate') 'to go from pillar to post'; ići s noge na nogu (lit. 'go from foot to foot') / идти нога за ногу (lit. 'go foot after foot') 'to drag one's feet'. 2b) Two idioms are grammatically equivalent: od jutra do sutra (lit. 'from morning till tomorrow') / од темна до темна (lit. 'from dark till dark') 'around the clock'; živjeti od prvoga do prvoga (lit. 'live from the first till the first') / жить от зарплаты до зарплаты (lit. 'live from paycheck to paycheck') 'live from paycheck to paycheck'. 3) Thirteen idioms are non-equivalent, e.g.: ni iz džepa ni u džep komu (lit. 'neither out of one's pocket nor into one's pocket) / ни ползы ни вреда кому (lit. 'neither the benefit ${ }_{G E N}$ nor harm GEN $_{\text {to }}$ sb') 'to have nothing to gain nor to lose'; smijati se od uha do uha (lit. 'laugh from ear to ear') / смеяться во весь рот (lit. 'laugh into one's whole mouth') 'smile from ear to ear'.

\section{Results of the comparison and conclusion}

The analysis has shown that Croatian and Russian are very similar in their use of antonymous prepositional pairs, which is to be expected due to their genetic relatedness. It also shows that prior experience in one language can help in learning the other, but that it can also have a negative influence when using the patterns in the examples that have differing grammatical and/or lexical structure between languages. Fillmore et al. [4] draws a distinction between substantive and formal idioms, however, structures with antonymous prepositional pairs can be placed on a scale from formal idioms to substantive idioms. In lexically open idioms, grammatical structure is equivalent between both languages (od podruma do krova - от подвала до крыши 'from cellar to roof'). Patterns with the same noun in both pairs are less lexically open (iz broja $u$ broj-из номера в номер 'from issue to issue'). Distributional patterns with temporal nouns (iz dana u dan - изо дня в день 'day after day', iz godine и godinu - из года в год 'year after year') are closer to substantive idioms, although the units used with nouns with temporal meaning can vary from smaller to larger ones. In all of these types, syntactic structure can be transferred from one language to another. Unlike in Croatian, the Russian structures $o m$ 'from' $-\kappa$ 'towards', $c$ 'from' - $\partial o$ 'to', $c$ 'from' $n o$ 'to' are also idiomatic and can be used in place of antonymous prepositional pairs. Although constitutive prepositions are equivalent in both languages when used separately, they cannot be transferred into Croatian when used as a pair (nереxoд om системы к системе > *prijelaz od sustava $\boldsymbol{k}$ sustavu / prijelaz sa sustava na sustav 'transition from system to system'). The substantive idioms in some examples are fully equivalent between the two languages ( $s$ koljena na koljeno - с поколения на поколение 'from generation to generation'), but many are not, and a direct translation from one language to another would result in an error. 


\section{Acknowledgements}

This paper is written within the research project Croatian Web Dictionary MREŽNIK (IP-2016-06-2141), financed by the Croatian Science Foundation.

\section{References}

1. Kovačević, B., Matas Ivanković, I.: Parni prijedlozi. Rasprave: Časopis Instituta za hrvatski jezik i jezikoslovlje 33(1), 245-261 (2008).

2. Всеволодова, М. В., Владимирский, Е. Ю.: Способы выражения пространственных отношений в современном русском языке. „Русский язык“, Москва (1982).

3. Всеволодова, М. В. Способы выражения временных отношений в современном русском языке. Издательство Московского университета, Москва (1975).

4. Fillmore, C.J., Kay, P., O'Connor, M.C. Regularity and Idiomaticity in Grammatical Constructions: The Case of Let Alone. Language 64(3), 501-538 (1988).

5. Menac, A., Fink Arsovski, Ž., Venturin, R.: Hrvatski frazeološki rječnik. Naklada Ljevak, Zagreb (2014).

6. Menac, A., Fink Arsovski, Ž., Mironova Blažina, I., Venturin, R.: Hrvatsko-ruski frazeološki rječnik + Kazalo hrvatskih i ruskih frazema. Knjigra, Zagreb (2011). 